Figure 1. Persistence of TCZ Therapy Among All TCZ Initiators, TCZ Initiators Excluding Those With No Reported Reason for Discontinuation and TCZ-IV Initiators

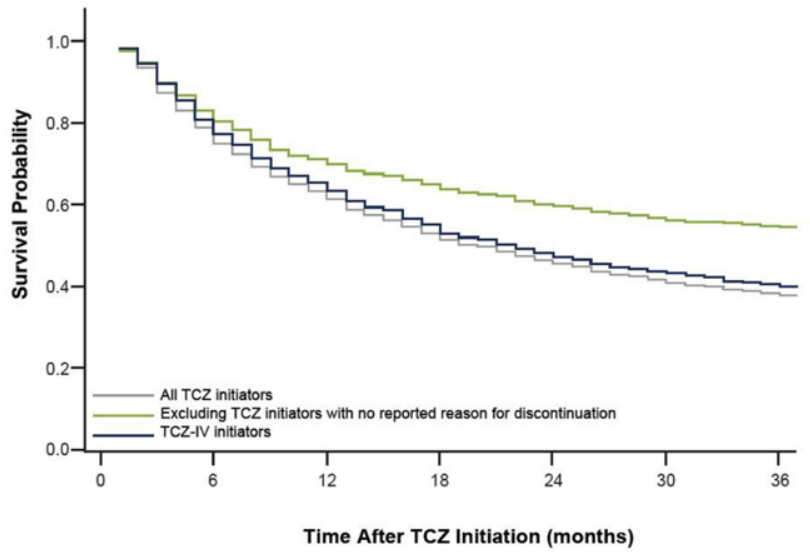

Number of

Patients at Risk

$\begin{array}{lllllll}1789 & 1245 & 861 & 636 & 483 & 378 & 298 \\ 1303 & 947 & 663 & 516 & 399 & 318 & 257 \\ 1284 & 921 & 644 & 482 & 376 & 307 & 244\end{array}$

IV, intravenous; TCZ, tocilizumab.

Figure 2. Estimated Effects of Covariates on Duration of TCZ Persistence Among (A) All TCZ Initiators, (B) TCZ Initiators Excluding Those With No Reported Reason for Discontiuation and (C) TCZ-IV Initiators$$
\text { A }
$$
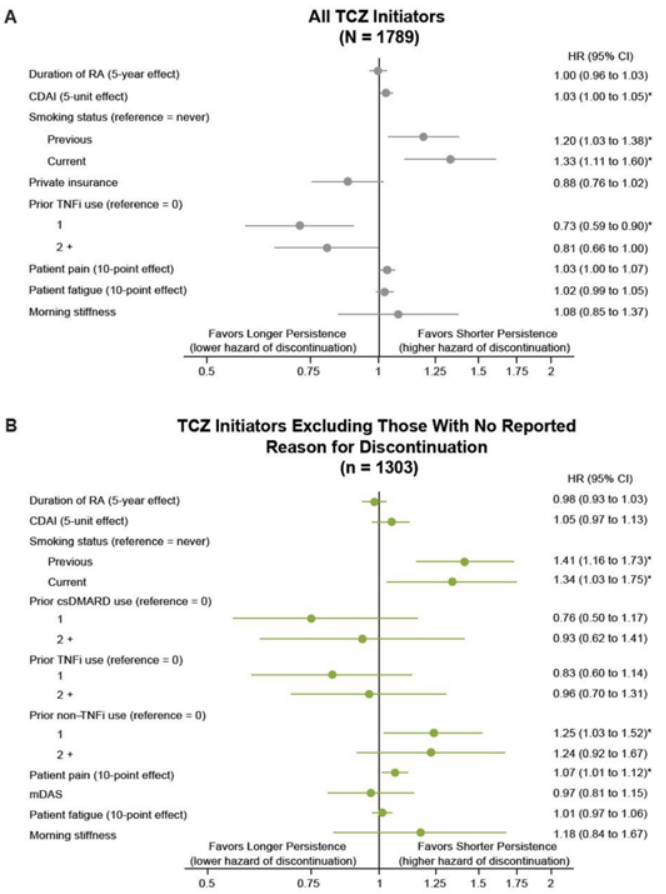

c

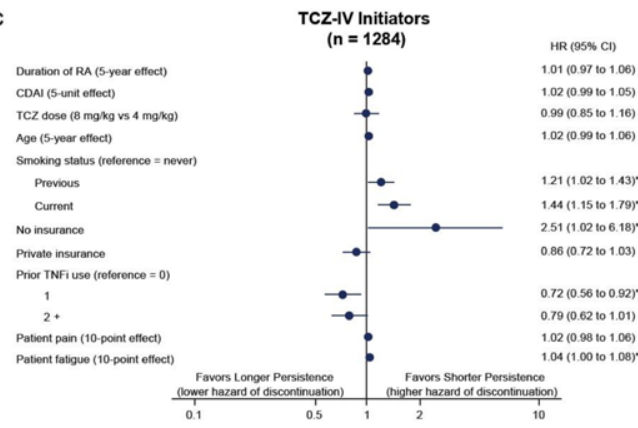

Acknowledgments: This study was sponsored by Corrona, LLC. Corrona is supported through contracted subscriptions with multiple pharmaceutical companies. The abstract was a collaborative effort between Corrona and Genentech, Inc., with financial support provided by Genentech, Inc.

Disclosure of Interests: Dimitrios A Pappas: None declared, Taylor Blachley Employee of: Corrona, LLC, Jennie H. Best Shareholder of: Genentech, Inc. Employee of: Genentech, Inc., Steve Zlotnick Shareholder of: Genentech, Inc. Employee of: Genentech, Inc., Kelechi Emeanuru Employee of: Corrona, LLC - employment, Joel M Kremer Shareholder of: May own stocks and opinions, Grant/research support from: Research and consulting fees from AbbVie Inc. Consultant of: AbbVie, Amgen, BMS, Genentech, Inc., Gilead, GSK, Lilly, Pfizer, Regeneron and Sanofi, Employee of: Corrona, LLC employee DOI: 10.1136/annrheumdis-2020-eular.708

FRI0105

\section{EVALUATION OF CXCL13 AND ICAM1 SERUM LEVELS AS PREDICTORS OF CLINICAL RESPONSE TO ABATACEPT IN RHEUMATOID ARTHRITIS.}

S. Piantoni ${ }^{1}$, S. Masneri ${ }^{1}$, F. Regola ${ }^{1}$, C. Nalli ${ }^{1}$, A. Tincani ${ }^{1}$, F. Franceschini ${ }^{1}$, P. Airò ${ }^{1}{ }^{1}$ ASST Spedali Civili and University of Brescia, Rheumatology and Clinical Immunology Unit, Clinical and Experimental Sciences, Brescia, Italy

Background: Soluble intercellular adhesion molecule 1 (ICAM1) and C-X-C motif chemokine 13 (CXCL13) were described as differentially associated with two major subtypes of synovitis in rheumatoid arthritis (RA). Raised serum levels of ICAM1 (which is upregulated in synovial fibroblasts in response to TNFa), and of CXCL13 (which is expressed by synovial follicular dendritic cells and activated mature antigen-experienced T-helper cells), are associated with a myeloid or lymphoid synovial phenotype, respectively (1). It has been suggested that a preferential clinical response to anti-TNFa, as compared to anti-IL-6R monotherapy, can be predicted by measuring these two biomarkers (2). No information is available on the possible utility of these biomarkers in RA patients treated with abatacept (ABA), a T-cell co-stimulation blocker.

Objectives: To analyze the effect of ABA on ICAM1 and CXCL13 serum levels in RA and to verify whether they predict the response to the drug.

Methods: $63 \mathrm{RA}$ patients $\left[\mathrm{F} / \mathrm{M}=51 / 12\right.$; median $\left(10^{\text {th }}-90^{\text {th }}\right.$ percentile $)$ age $=60$ (41-72) years; CRP-DAS28=4.6 (3.3-5.8); ACPA positive: $86 \%]$, before and after 6 months of treatment with ABA + methotrexate and 22 sex and age-matched healthy controls $(\mathrm{HC})$ were evaluated. Serum ICAM1 and CXCL13 levels were dosed by commercial ELISA (Life Technologies and R\&D). Response to treatment was defined with the EULAR criteria.

Results: CXCL13 serum levels were higher in RA at baseline than in HC [136 (42-325) vs $32(19-57) \mathrm{pg} / \mathrm{ml}, \mathrm{p}<0.01]$, while no difference was observed in ICAM1 [186 (125-276) vs $184(153-246) \mathrm{ng} / \mathrm{ml}, \mathrm{p}=0.9$ ]; positive correlations between ICAM1 and CRP ( $r: 0.28 ; p=0.03)$ and CXCL13 levels and CRP ( $r: 0.40$ $p<0.01)$ and CRP-DAS28 values $(r: 0.27, p=0.05)$ were found. After therapy with ABA, a reduction of CXCL13 was observed [136 (42-325) vs 94 (29-319) pg/ml, $\mathrm{p}<0.01$ ], both in responders [n: $37: 151$ (57-462) vs $97(26-329) \mathrm{pg} / \mathrm{ml} ; \mathrm{p}<0.01$ ] and non-responders (n: 14: $142(68-293)$ vs $89(42-198) \mathrm{pg} / \mathrm{ml} ; \mathrm{p}=0.01]$. Not significant variation of ICAM1 serum levels was found in the entire cohort [186 $(125-276)$ vs 190 (113-252) $\mathrm{ng} / \mathrm{ml}, \mathrm{p}=0.06]$. However, a significant decrease was observed in non-responders [222 (169-302) vs $186(110-233) \mathrm{ng} / \mathrm{ml}, \mathrm{p}=0.02]$. At baseline, no significant difference was found among patients seropositive for ACPA if compared with the negative ones [ACPA+ vs ACPA- for ICAM1 [187 (123-280) vs 177 (134-258) ng/ml; $p=0.7]$ and for CXCL13 [143 (42-368) vs 113 (56-270) $\mathrm{pg} / \mathrm{ml} ; \mathrm{p}=0.4]$ ].

Conclusion: Our results confirmed that CXCL13 serum levels are directly correlated with disease activity and demonstrated that $A B A$ therapy induces their reduction. These findings suggest that the co-stimulation blockade at central level and/or in the synovium lead to a reduced production of CXCL13. We could not demonstrate that $\mathrm{CXCL} 13$ levels predict the clinical response to $A B A$ in this cohort of patients.

References:

[1] Rosengren S, Rheumatology 2011;2.Dennis G, Arthritis Res Ther 2014 Acknowledgments: Bristol-Myers-Squibb Italy provided an unrestricted research grant for the study conduction.

Disclosure of Interests: None declared

DOI: 10.1136/annrheumdis-2020-eular.3761

\begin{tabular}{|l|l|}
\hline FRI0106 & RISK FACTORS FOR SERIOUS INFECTIONS IN \\
& PATIENTS WITH RA INITIATING TREATMENT WITH \\
& BIOLOGIC DMARDS: A REAL-WORLD POPULATION- \\
& BASED OBSERVATIONAL STUDY
\end{tabular}

S. Suissa ${ }^{1}$, P. Brassard ${ }^{1}$, A. L. Dominique ${ }^{2}$, T. Simon ${ }^{3}$, M. Hudson ${ }^{1} .{ }^{1}$ Mc Gill University, Montreal, Canada; ${ }^{2}$ Bristol-Myers Squibb, Princeton, United States of America; ${ }^{3}$ Independent, Toms River, United States of America 